\title{
Syntheses of New Antimicrobial Cellulose Materials Based 2-((2-aminoethyl)amino)-4-aryl-6-indolylnicotinonitriles
}

\author{
Naglaa S. EL-Sayed ${ }^{1}$, A.K. El-Ziaty ${ }^{2}$, Magda G. El-Meligy ${ }^{1}$, Zenat A. Nagieb ${ }^{1 *}$ \\ ${ }^{1}$ Cellulose and Paper Department, National Research Centre, Dokki and ${ }^{2}$ Organic \\ Chemistry Department, Faculty of Science, Ain Shams University, Abbassia, Cairo \\ 11566, Egypt
}

\begin{abstract}
2 -((2-aminoethyl)amino)-4-aryl-6-indolylnicotinonitriles (1a-c), were grafted into two 2 different cellulosic intermediates, where 6-deoxy tosyl cellulose that was prepared by the reaction of microcrystalline cellulose (MCC) with tosyl chloride in DMA/LiCl. Additionally, the dialdehyde carboxymethyl cellulose (2,3-DACMC) obtained by regioselective periodate oxidation of carboxymethyl cellulose (CMC) were also condensed with the same amine compounds (1a-c) via Schiff's base reaction aiming to obtain new functionalized amino cellulosic derivatives with predictable applications. The products were characterized by FT-IR, ${ }^{13} \mathrm{C}-\mathrm{NMR}$, elemental analysis, SEM, and X-ray diffraction. The antimicrobial activity of the new cellulose amine derivatives and Schiff's bases of (2,3-DACMC) were assayed on four different microorganisms. Among the tested compounds, (3a) and (3b) proved to be promising antimicrobial cellulosic material that could be used as a broad spectrum wound healing gels or manufacturing of packaging materials.
\end{abstract}

Keywords: Heterocyclic amino compounds, 6-deoxycellulose tosylate, Schiff's base, CMC, Periodate oxidation, Antimicrobial activity..

\section{Introduction}

Nicotinonitrile skeletons especially those with an amino group at $\mathrm{C}_{2}$ and/or 4,6-diaryl-substitutents have demonstrated a broad range of biological activities, such as antibacterial [1], antifungal[2] antituberculosis [3], antiviral[4], analgesic, and anti-inflammatory effects $[5,6]$. Furthermore, they have been used as inhibitors of adenosine kinase, topoisomerase [7], anti-proliferative agents that have been used for the treatment of a number of human cancer cell lines [8 - 10].

The chemical modification of cellulose is done in order to obtain different kinds of cellulosic derivatives that diverse in their physical and chemical features and could be used in several industrial and environmental applications. The poor solubility of cellulose in water and most common organic solvents is the major obstacle for cellulose reactivity and subsequent modification[11,12]. This is due to the intra and intermolecular hydrogen bonds along the polymer chains. The solubility of cellulose sulfonates particularly cellulose tosylate in organic solvents made them suitable key intermediate for selective nucleophilic substitution reactions on C-6 of anhydroglucose unit during cellulose functionalization $[13,14]$. The broad spectrum antimicrobial properties of amino cellulose as well as their good biocompatibility made them suitable candidate for the design of novel amino cellulose biopolymers through the chemical grafting of cellulose by amino compounds. Recently, there is an increasing interest for the preparation of new amino cellulose derivatives for their potential applications in different research fields, such as anion-exchange resin, selective membranes [12,13], anticoagulants, biosensors, enzyme immobilization in bioassays [14-16], flame retardants[17], and antimicrobial agents [18]. The antimicrobial activity of the modified natural polysaccharides, such as some chitosan

*Corresponding author e-mail: zenat.ad@gmail.com 
and starch derivatives encouraged their use in the manufacturing of packaging materials. However, their water solubility and durability are the main drawbacks that hinder their applications in food packaging industries[19].

Moreover, carboxymethyl cellulose (CMC) is water-soluble anionic cellulose derivative. It widely used in many industrial pharmaceutics, cosmetics, drug delivery, and wound dressing because of their high water absorption property, gelation behavior, bio-degradability, and biocompatibility[20-22]. Additionally, Schiff bases has received great attention due to their reported biological activities[23,24]. In this report we described the synthesis, characterization and antimicrobial activity of new cellulose amine derivatives, and new CMC based Schiff's bases using 2-((2-aminoethyl)amino)-6-(1H-indol-3yl)-4-aryl nicotinonitriles (1a-c) which have been synthesized by our group [10] and evaluated for their biological potency as antiproliferating and antimicrobial agents.

\section{Experimental}

\section{Materials}

Microcrystalline cellulose MCC (Merk, DP 225), Carboxymethyl cellulose sodium salt CMC medium viscosity, degree of substitution of $0.65-$ 0.90 was purchased from Fluca, Sodium periodate $\left(\mathrm{NaIO}_{4}\right)$, p-toluenesulfonyl chloride, Dimethyl acetamide (DMA), anhydrous lithium chloride $\mathrm{LiCl}$, triethyl amine $\left(\mathrm{Et}_{3} \mathrm{~N}\right)$ were purchased from sigma aldrich, the materials were used as received. IR spectra were recorded on JASCO FT/ IR 6100 Japan spectrometer (NRC, Dokki, Giza, Egypt) using $\mathrm{KBr}$ disc. ${ }^{13} \mathrm{C}$-NMR spectra were determined using JEOL ECA-500 run for 125 $\mathrm{MHz}$ spectrometer (NRC, Dokki, Giza, Egypt). Chemical shifts were expressed in part per million $\delta(\mathrm{ppm})$ against tetramethylsilane (TMS) as an internal standard. The samples of MCC, TsMCC and cellulose amines 2a-c were imaged using JEOL JXA-840A Scanning electron microscope (NRC, Dokki, Giza, Egypt).The X-ray diffraction profiles for CMC, 2,3-DACMC, and Schiff"s bases (3a-c) were obtained using a Philips 1730 X-ray diffractometer (National Research Center Cairo, Egypt). All reactions were followed up by thin layer chromatography (TLC) using aluminum sheets recoated with UV fluorescent silica gel (Merck Kieselgel 60 F245), UV lamp, and ninhydrine solution.

Egypt.J.Chem. 60 , No.3 (2017)

\section{Methods}

Tosylation of cellulose was carried out according to the method described by Rahn et al.[26] in two step.

\section{Step 1: dissolution of $\mathrm{MCC}$ in $\mathrm{DMA} / \mathrm{LiCl}$}

MCC was dried at $70^{\circ} \mathrm{C}$ for $72 \mathrm{~h}$ in oven. Then, $(120 \mathrm{~mL})$ of DMA was added to MCC (5.0 $\mathrm{g}, 30.8 \mathrm{mmol}$ of anhydroglucose unit) in $500 \mathrm{~mL}$ round flask, and stirred at $130^{\circ} \mathrm{C}$ for $2 \mathrm{~h}$ where a colorless slurry is observed. The slurry had been allowed to cool down to $100^{\circ} \mathrm{C}$, Then, $(10$ g) of anhydrous $\mathrm{LiCl}$ in $(25 \mathrm{ml})$ of DMA were added under stirring. The stirring was continued overnight at room temperature until the complete dissolution of cellulose.

\section{Step 2: tosylation of $M C C$}

A mixture of TEA (18.6 mL, $185 \mathrm{mmol}, 6 \mathrm{~mol} /$ AGU) in $(10 \mathrm{~mL})$ DMA was added to the solution of $\mathrm{MCC}$ under stirring at room temperature, the stirring was continued for another $30 \mathrm{~min}$, followed by drop wise addition of a solution of p-toluenesulfonyl chloride $(35.3 \mathrm{~g}, 184.8 \mathrm{mmol}$, $6 \mathrm{~mol} / \mathrm{mol} \mathrm{AGU}$ dissolved in $25 \mathrm{~mL}$ of DMA) over a period of $30-60 \mathrm{~min}$. at $3-8{ }^{\circ} \mathrm{C}$. The stirring was continued for another $24 \mathrm{~h}$ at room temperature, then the mixture was poured slowly into $(1 \mathrm{~L})$ of ethanol. The precipitate was filtered off, washed carefully with about (1L) of distilled water, suspended in $250 \mathrm{~mL}$ of boiling acetone and reprecipitated in distilled water $(500 \mathrm{~mL})$, and filtered off. Then washed with ethanol $(250 \mathrm{~mL})$ for three times, to remove the unreacted $\mathrm{TsCl}$. The resulted TsMCC was dried at $50{ }^{\circ} \mathrm{C}$ in oven for 48h. Yield: $65 \%$, elemental analysis: $C=45.63$, $\mathrm{H}=5.49, \mathrm{~S}=6.11$.

The degree of substitution (DS) was determined by sulfur analysis and calculated according to the equation:

$\mathrm{DS}=\mathrm{M}_{\mathrm{AUG}} * \mathrm{~S}(\%) / \mathrm{M}_{\mathrm{S}} * 100(\%)-\mathrm{M}_{\mathrm{Tos}} * \mathrm{~S}(\%)[26]$

where $\mathrm{M}_{\mathrm{AUG}}$ denotes the molar mass of $\mathrm{AGU}$ $(\mathrm{AGU}=162)$, MS is the molar mass of sulfur ( $\mathrm{S}$ $=32$ ), $\mathrm{M}_{\text {Tos }}$ is the molar mass of the tosyl group $(\mathrm{Ts}=155)$.

$\mathrm{DS}_{\mathrm{Ts}}=162 * 0.0611 / 32 * 100(\%)-155^{*}$ $0.0611=0.44$.

\section{Characterization of Ts $M C C$}

IR (KBr, v/cm $\left.{ }^{-1}\right): 3442\left(\mathrm{OH}{ }_{\mathrm{str}}\right), 1383\left(\mathrm{SO}_{2}\right.$ asym $), 1177\left(\mathrm{SO}_{2 \text { sym }}\right), 812 \mathrm{~cm}^{-1}(\mathrm{~S}-\mathrm{O}-\mathrm{C}) \cdot{ }^{13} \mathrm{C}-\mathrm{NMR}$ (DMSO-d $)_{6} \delta$ ppm: $21.65\left(\mathrm{SP}^{3}, \mathrm{p}-\mathrm{CH}_{3}\right.$ of $\mathrm{Ts}$ group), 56.57, 69.04, 71.07, 72.48, 75.37, 76.15, 
81.02, 98.96, $101.24\left(\mathrm{SP}^{3}, \mathrm{C}-6_{\text {non-Ts }}, \mathrm{C}-6_{\mathrm{Ts}}, \mathrm{C}-5\right.$, C-4, C-3, C-2, and C-1), 128.30, 130.17, 137.35, and 145.98 (4 signals for $6 \mathrm{SP}^{2}$ carbon atoms of the substituted Ts group).

Substitution of tosyl group by 2-((2-Aminoethyl) amino)-6-(1H-indol-3-yl)-4-(aryl) nicotinonitrile $(1 a-c)$

A series of cellulose amine derivatives (2a-c) were prepared by the substitution of tosyl group by 2-((2-Aminoethyl) amino)-6-(1H-indol-3-yl)4-(aryl) nicotinonitrile (1a-c) according to the following method: TsMCC, $\mathrm{DS}_{\mathrm{Ts}}=0.44(1 \mathrm{~g}, 2.1$ $\mathrm{mmol} / \mathrm{AGU}$ ) was dissolved in DMF (1 mL). Then $(75 \mathrm{mg})$ of the proper amine solution (1a-c) in (1 $\mathrm{mL})$ of DMF containing $(100 \mu \mathrm{L})$ of triethyl amine were added drop wise to the TsMCC solution. The mixture was stirred at $90{ }^{\circ} \mathrm{C}$ for $24 \mathrm{~h}$. The progress of the reaction was monitored by TLC and the heterocyclic amine grafting was visualized by ninhydrine stain, untile the disappearance of the violet spot on the TLC which means the amine reacted completely. After completing the reaction, the product was separated by precipitation in ethanol $(200 \mathrm{~mL})$. The solid products were filtered off, purified by boiling in acetone $(500 \mathrm{~mL}$ for 3 times), filtered off, and dried at $50{ }^{\circ} \mathrm{C}$ in oven for 48h. The structure of the new cellulose amine derivatives (2a-c) were confirmed by elemental analysis, IR, and ${ }^{13} \mathrm{C}-\mathrm{NMR}$.

Characterization of cellulose amine (2a)

Elemental analysis: C; 43.23, H; 5.79, N; 2.10, S; 1.72. IR $\left(\mathrm{KBr}, \mathrm{v} / \mathrm{cm}^{-1}\right): 3423$ (broad, $\mathrm{NH}_{\text {str. }}$ and $\left.\mathrm{OH}{ }_{\text {str. }}\right), 2924\left(\mathrm{C}-\mathrm{H}_{\text {str. }}\right.$ ), 2201 (CN), $1608\left(\mathrm{C}=\mathrm{N}_{\text {aromatic }}\right)$, and 1589 (indolyl $\left.\mathrm{NH}_{\text {bending }}\right)$ : ${ }^{13} \mathrm{C}-\mathrm{NMR}$ (DMSO-d $) \quad \delta$ ppm: 21.98 (2 SP3, p- $\mathrm{CH}_{3}$ of Ts group), 46.36, 47.64 (2 signals for 2 $\mathrm{CH}_{2}$ of indolylnicotinonitrile 1a), 56.44 (OCH3), 59.86, 69.80, 71.74, 73.38, 75.12, 76.26, 79.25, 100.45, 101.16 (C-6 non-Ts, C-6 Ts, C-5, C-4, $\mathrm{C}-3$, and $\mathrm{C}-2$ and $\mathrm{C}-1$ of $\mathrm{AGU}), 109.88$ (CN), $86.55,114.46,115.31,118.47,118.58,119.50$, $122.52,123.40,124.87,128.69,129.05,130.13$, $135.80,137.46,146.15,147.63,155.94,157.78$, 163.06, and 166.43 (20 signal for different $\mathrm{SP}^{2}$ aromatic carbons of substituted Ts groups, and the indolylnicotinonitrile 1a along the cellulose chain).

Characterization of cellulose amine (2b)

Elemental analysis: C; 43.83, H; 5.84, N; 1.42, S; 2.86. IR (KBr, v/cm-1): 3419 (broad, $\mathrm{NH}_{\text {str. }}$ and $\left.\mathrm{OH}_{\text {str. }}\right), 2924\left(\mathrm{C}-\mathrm{H}_{\text {str. }}\right), 2204$ (CN), and $1602(\mathrm{C}=\mathrm{N}$ aromatic $) \cdot{ }^{13} \mathrm{C}-\mathrm{NMR}\left(\mathrm{DMSO}-\mathrm{d}_{6}\right) \delta$ ppm: 21.65 (p-CH3), 46.21, 48.05 (2 signals for $2 \mathrm{CH}_{2}$ of indolylnicotinonitrile $\left.1 \mathrm{~b}\right), 63.64,71.32$, 73.48, 74.99, 78.23 99.66, and 101.21 (C-6 non-Ts' $\mathrm{C}-6_{\mathrm{Ts}}, \mathrm{C}-5, \mathrm{C}-4, \mathrm{C}-3$ and $\mathrm{C}-1$ of AGU), 107.88 (SP, CN), 85.20, 115.19, 115.68, 119.01, 119.33, $122.57,123.35,126.03,126.57,128.24,128.63$, $130.78,131.07,135.05,135.37,146.27,146.56$, $158.28,159.19,160.90$, and 164.01 (20 signal for different $\mathrm{SP}^{2}$ aromatic carbons of substituted Ts groups, and the indolylnicotinonitrile $1 \mathrm{~b}$ along the cellulose chain).

Characterization of cellulose amine (2c)

Elemental analysis: C; 46.47, H; 5.78, N; 1.60, S; 3.42. IR (KBr, v/ $\left./ \mathrm{cm}^{-1}\right): 3413$ (broad, $\mathrm{NH}$

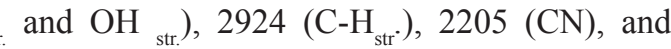
$1596\left(\mathrm{C}=\mathrm{N}_{\text {aromatic }}\right.$, and indolyl $\left.\mathrm{NH}_{\text {bending }}\right) .{ }^{\text {str. }} \mathrm{C}-\mathrm{NMR}$ $\left(\right.$ DMSO- $\left.\mathrm{d}_{6}\right) \delta$ ppm: $21.75\left(\mathrm{p}-\mathrm{CH}_{3}\right), 45.72,46.33$ ( 2 signals for $2 \mathrm{CH}_{2}$ of indolylnicotinonitrile $1 \mathrm{c}$ ), 60.82, 69.63, 73.85, 75.46, 78.34, 102.74 (C-6 ${ }_{\mathrm{Ts}}$, C-6 ${ }_{\mathrm{Ts}}, \mathrm{C}-5, \mathrm{C}-4, \mathrm{C}-3, \mathrm{C}-2$, and C-1 of AGU), $107.29(\mathrm{CN}), \quad 86.50,113.65,116.08,119.00$, $122.47,123.56,127.90,128.79,129.13,130.96$, 131.54, 135.44, 138.64, 145.38, 146.98, 151.75, $155.50,157.98,160.43$, and 163.58 (20 signal for different $\mathrm{SP}^{2}$ aromatic carbons of substituted tosyl groups, and the indolylnicotinonitrile $1 \mathrm{c}$ along the cellulose chain).

\section{Scanning electron microscope SEM}

The samples of MCC, TsMCC and 2a-c were imaged using JEOL JXA-840A Eletron probe microanalyzer, by sprinkling onto an aluminum stub that was covered with carbon.

Periodatate oxidation of carboxymethylcellulose $C M C$ :

The oxidation of carboxymethyl cellulose was carried out according to the method described by E. Bordallo et al. [22] Where carboxymethyl cellulose (5 g, $24 \mathrm{mmol}$ of AUG) was dissolved in $(100 \mathrm{~mL})$ of distilled water by stirring at room temperature for $24 \mathrm{~h}$ until complete dissolution. Then, $\mathrm{NaIO}_{4}(5 \mathrm{~g}, 23.5 \mathrm{mmol})$ was dissolved in (10 $\mathrm{mL}$ ) of water and added to the CMC solution drop wise, the $\mathrm{pH}$ was adjusted to 3 by sulfuric acid, and the mixture was stirred in the dark at $35^{\circ} \mathrm{C}$ for $48 \mathrm{~h}$. The excess of periodate was decomposed by adding $(20 \mathrm{~mL})$ of ethylene glycol to the reaction mixture and further stirring for $1 \mathrm{~h}$ to stop the oxidation reaction. Then $(500 \mathrm{~mL})$ of ethanol was added to precipitate the product of 2,3-dialdehyde carboxymethyl cellulose (2,3-DACMC), which is filtered off, and washed several times with ethanol/ 
water $(90 / 10, \mathrm{v} / \mathrm{v}) .2,3-\mathrm{DACMC}$ was suspended in another $(500 \mathrm{~mL})$ of acetone and stirred for 10 $\mathrm{min}$, and filtered off. The white powder was dried under vacuum for $3 \mathrm{~h}$, and at $50{ }^{\circ} \mathrm{C}$ for $24 \mathrm{~h}$.

Elemental analysis for 2,3-DACMC: C; $46.76 \%, \mathrm{H} ; 5.52 \%$, N; 0\%, IR (KBr, v/ $\left.\mathrm{cm}^{-1}\right): 3466$ (br, $\left.\mathrm{OH}_{\text {str. }}\right), 2930\left({\mathrm{C}-\mathrm{H}_{\text {str }}}\right), 1738\left(\mathrm{CO}_{\text {str. aldehydic }}\right)$, 1632 ( $\mathrm{CO}$ carboxyl $), 889$ (hemiacetal bond between the hydroxyl group and the aldehyde group).

Determination of the aldehyde content of 2,3-DACMC

The degree of oxidization of CMC was evaluated by the determination of the aldehyde content by the oxime formationmethod as described by Kim et. al [30]. Where $0.5 \mathrm{~g}$ 2,3-DACMC was dissolved in $(5 \mathrm{~mL})$ distilled water and the $\mathrm{pH}$ was adjusted to 5 by sodium hydroxide solution. Then, a solution of hydroxylamine hydrochloride (20 $\mathrm{mL}, 1 \mathrm{~g}, 0.014 \mathrm{~mol}$ ) was added to 2,3-DACMC solution. The mixture was stirred at $40 \mathrm{oC}$ for $24 \mathrm{~h}$. Then the reaction mixture was titrated against the resulted hydrochloric acid with $(1 \mathrm{~N}) \mathrm{NaOH}$. The volume used from $\mathrm{NaOH}$ solution was recorded as $\mathrm{V}_{\text {sample }}$. The same procedure was applied on the blank sample of CMC and its consumption of the $\mathrm{NaOH}$ solution was expressed as $\mathrm{V}_{\text {blank. }}$ Thus, the $\%$ of aldehyde content (AC) in 2,3-DCMC can be calculated by that equation:

$\mathrm{AC}=\mathrm{M}_{\mathrm{NaOH}} *\left(\mathrm{~V}_{\text {sample }}-\mathrm{V}_{\text {blank }}\right) / \mathrm{m} / 211 \times 100$.

where $\mathrm{M}_{\mathrm{NaOH}}=1.0 \mathrm{~mol} / \mathrm{L}, \mathrm{m}$ is dry weight of 2,3-DACMC sample in $\mathrm{g}$, and 211 is the molecular weight of oxidized ahydroglucose unit in 2,3-DACMC. The experiment was repeated for three times to take the average.

Schiff's base formation (3a-c):

$(75 \mathrm{mg})$ of 2-((2-Aminoethyl)amino)-6-(1Hindol-3-yl)-4-aryl-nicotinonitrile (1a-c) was dissolved in $(1 \mathrm{~mL})$ of DMF containing (136 $\mu \mathrm{L}$ ) of trimethylamine and stirred for $15 \mathrm{~min}$. Then the amine solution was slowly added under stirring to a solution of 2,3-DACMC (1 g, 4.7 mmol) dissolved in (5-7 mL) of distilled $\mathrm{H}_{2} \mathrm{O}$, the ratio of grafting is 13 of $2,3-\mathrm{DACMC}: 1^{2}$ of the proper amine wt: wt. the reaction mixture was stirred in darkness at $50{ }^{\circ} \mathrm{C}$ until the reaction was completed, where the progress of the reaction was monitored by TLC, and a solution of ninhydrine was used to visualize the unreacted amine. After completing the reaction that evidenced by the disappearance of the heterocyclic amine spot on the TLC, the mixture was poured into $(250 \mathrm{~mL})$ Egypt.J.Chem. 60 , No.3 (2017) of acetone and the resulted precipitate was filtered off, washed with another $(250 \mathrm{~mL})$ of methanol, and vacuum dried. The structure of the Schiff base products was confirmed by elemental analysis, IR, and XRD. The solubility difficulties of Schiff"s bases hindered their NMR analysis.

Characterization of Schiff base (3a)

Elemental analysis: C; 43, H; 5.76, N; 1.29, IR $\left(\mathrm{KBr}, \mathrm{v} / \mathrm{cm}^{-1}\right): 3376$ (br, OH ${ }_{\text {str. }}, \mathrm{NH}_{\text {str. }}, 2927(\mathrm{C}-\mathrm{H}$ $\left.{ }_{\text {str }}\right), 2210(\mathrm{CN}), 1606$ and $1578(\mathrm{C}=\mathrm{N}$ aromatic $)$.

Characterization of Schiff 's base (3b)

Elemental analysis: C; 39.33, H; 5.38, N; 1.22, IR (KBr, v/cm $\left.{ }^{-1}\right): 3426$ (br, $\mathrm{OH}_{\text {str. }}, \mathrm{NH}_{\text {str. }}$ ),

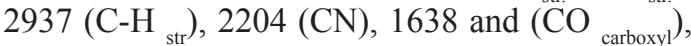
and $1585\left(\mathrm{C}=\mathrm{N}_{\text {aromatic }}\right)$.

Characterization of Schiff s base (3c)

Elemental analysis: C; 42.41, H; 3.60, N; 1.55, IR $\left(\mathrm{KBr}, \mathrm{v} / \mathrm{cm}^{-1}\right): 3418$ (br, $\left.\mathrm{OH}_{\text {str }}, \mathrm{NH}_{\text {str. }}\right), 2925$ $\left(\mathrm{C}-\mathrm{H}_{\text {str }}\right), 2202(\mathrm{CN})$, and $1594\left(\mathrm{C}=\mathrm{N}_{\text {aromatic }}\right)$.

\section{$X$-ray diffraction measurements}

The X-ray diffraction profiles for $\mathrm{CMC}$, 2,3-DACMC, and Schiff bases (3a-c) were obtained. The diffraction patterns were recorded using nickel-filtered $\mathrm{Cu}$ as target with a secondary monochromator at $45 \mathrm{kV}$ and $30 \mathrm{~mA}$. The samples were scanned in the range of diffraction angle $(2 \theta)$ from $5^{0}$ to $75^{\circ}$ with a scanning rate of 20/min at ambient temperature and humidity. The crystallinity index $(\mathrm{CrI})$ was calculated via the equation[30].

$\mathrm{CrI}=\left[\left(\mathrm{I}_{002}-\mathrm{I}_{\mathrm{am}}\right) / \mathrm{I}_{002}\right]$ where $\mathrm{I}_{002}$ is the intensity in the diffraction profile at the position of the 002 peak, and Iam is the intensity at locations for the amorphous background.

\section{The antimicrobial assay}

The antimicrobial activity of compounds (1a-c) at concenrations of $20 \mu \mathrm{g} / \mathrm{ml}$, MCCTs, 2a-c, 2,3-DACMC, and Schiff"s bases (3ac) at concentrations $\left(200 \mathrm{mg} / \mathrm{mL}\right.$ in $50 \% \mathrm{H}_{2} \mathrm{O} /$ DMSO) were screened against four different microorganisms including the gram positive (Bacillus subtilis, Staphylococcus aureus), and the gram negative (Escherichia coli) and Candida as (yeast) by well diffusion method[32]. Where the prepared nutrient agar media were inoculated with the microorganism and wells were made on the agar surface with $1 \mathrm{~mm}$ cork borer. Then $(100 \mu \mathrm{L})$ of each compound was added to each well in the plates. The plates were incubated at $37 \mathrm{C}^{\circ}$ for 24 
hours, the inhibition zones around the wells were measured. Compounds 2,3-DACMC, $3 \mathrm{a}$ and $3 \mathrm{~b}$ were selected as the most promising antimicrobial agents for further screening in order to determine the minimum inhibitory concentration. Each microorganism was seeded by $(100 \mu \mathrm{L})$ from the different polymer concentrations $(50,100$, and $300 \mathrm{mg} / \mathrm{mL}$ ). The readings were taken in three different fixed directions and the average values were tabulated.

\section{Results and Discussion}

\section{Tosylation of cellulose}

In this study, we used microcrystaline cellulose MCC with (DP) 225, determined by viscosity measurement for a sample dissolved in copper-ammonium hydroxide solution[25]. 6-Deoxycellulose tosylate (TsMCC) as an active intermediate was prepared following the method described by Rahn et al.[26] Where 6 mole equivalent of p-toluenesulfonyl chloride per anhydroglucose unit was used as a tosylting agent, while trimethylamine was used as a base catalyst. The reaction was carried out under homogenous dissolution system using DMA/LiCl. The reaction was conducted at low temperature $\left(3-8^{\circ} \mathrm{C}\right)$ to avoid the formation of 6-chlorodeoxy cellulose which was reported to occur at elevated temperatures[27]. Based on the elemental analysis for the sulfur content, the DSTs value for the tosyl groups on cellulose chains was found to be 0.44 . It is worth to mention that, the tosylation reaction usually takes place preferably on the primary hydroxyl group at C-6 of the AGU which is more reactive than the other secondary hydroxyls at $\mathrm{C}-3$ and $C^{-2}[26]$.

The IR spectrum $\left(\mathrm{KBr}, \mathrm{v} / \mathrm{cm}^{-1}\right)$ revealed the existence of characteristic vibrational bands at 1383 for $\left(\mathrm{SO}_{2}\right.$ asym $)$, and 812 for (S-O-C). The ${ }^{13} \mathrm{C}-\mathrm{NMR}$ (DMSO-d ${ }_{6}$, demonstrated typical peaks $\delta$ (ppm): 21.75 ( $\mathrm{SP}_{3}, \mathrm{p}-\mathrm{CH}_{3}$ of Ts group), $56.57,69.04$ for $\mathrm{C}-6_{\text {non-Ts }}, \mathrm{C}-6_{\mathrm{Ts}}$, and 128.30, $130.17,137.35$, and 145.98 that are corresponds to the phenyl ring of the substituted Ts group. So far, the data obtained was compatible with that in literature(12-14,26). With the degree of tosyl substitution 0.44 , the resulted TsMCC was soluble in organic solvents including acetone, DMF, dioxin, and DMSO.
Substitution of tosyl groups by 2-((2-aminoethyl) amino)-6-(1H-indol-3-yl)-4-aryl nicotinonitrile $(1 a-c)$ :

The strategy involves the replacement of the Ts group which is known to be a good leaving and cellulose activating group by the heterocyclic amine (1a-c) using a catalytic amount of triethylamine (Scheme 1). The ratio of grafting between TsMCC: heterocyclic amine was 13: $1 \mathrm{Wt} / \mathrm{Wt}, 1$. The products were confirmed by the elemental analysis, FT-IR, and ${ }^{13} \mathrm{C}-\mathrm{NMR}$.

Taking compound (2c) as an example, the decrease of sulfur content and the increase in the nitrogen content reflects the partial substitution of the tosyl groups by the corresponding amine derivative. Additionally, the IR spectrum revealed the presence of stretching vibrational band at $3413 \mathrm{~cm}^{-1}$ for $(\mathrm{OH}$, and $\mathrm{NH}), 2205 \mathrm{~cm}^{-1}$ for the $(\mathrm{CN})$ group and the absorption band at $1596 \mathrm{~cm}^{-1}$ which was assigned to the $\left(\mathrm{C}=\mathrm{N}_{\text {aromatic }}\right)$. The ${ }^{13} \mathrm{C}$-NMR (DMSO-d $) \delta(\mathrm{ppm})$ showed the following signals $21.75\left(\mathrm{p}-\mathrm{CH}_{3}\right), 45.72,46.33$ (2 signals for $2 \mathrm{CH}_{2}$ of indolylnicotinonitrile 1c), 107.29 for $(\mathrm{CN})$, and the signals from 86.50-163.58 are attributed to 20 signal for different $\mathrm{SP}^{2}$ aromatic carbons of substituted tosyl groups, and the indolylnicotinonitrile 2c along the cellulose chain).

\section{Characterization by scanning electron microscopy (SEM)}

The morphological characteristics of TsMCC, and cellulose amine derivatives (2a-c) were studied and compared to the unmodified MCC. The elongated fibrous structure of MCC changed to porous, interconnected, sheets like structure in TsMCC. In case of cellulose amine derivatives, no notable changes in the morphology in compounds $(2 \mathrm{a}$, and $\mathrm{b})$ from TsMCC. However, amino cellulose derivative (2c) showed laminar porous pattern. The tosyl groups and aminoindolyl nicotinonitrile (1ac) can be noticed on the surface of cellulose polymer chains (Fig. 1).

\section{Oxidation of CMC by sodium periodate}

The regioselective oxidation of $\mathrm{CMC}$ was carried out by using sodium periodate. It is known that, the periodate is a selective mild oxidizing agent that is usually used to oxidize the vicinal $\mathrm{OH}$ at $\mathrm{C}-2$ and $\mathrm{OH}$ at $\mathrm{C}-3$ in the $\mathrm{AGU}[29,30]$ of cellulose leading to ring 

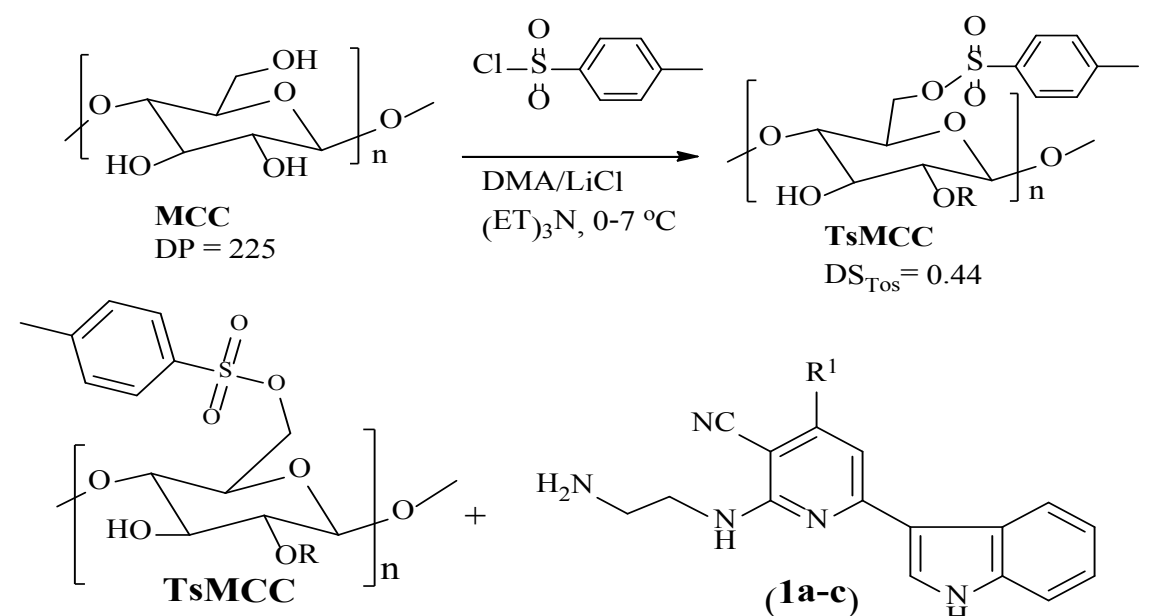<smiles>[Y9][Z19]=C(NCCN)c1nc(-c2c[nH]c3ccccc23)cc([R1])c1C#N</smiles>

$$
\mathrm{R}=\mathrm{H} \text {, or } \mathrm{Ts}
$$

Scheme 1

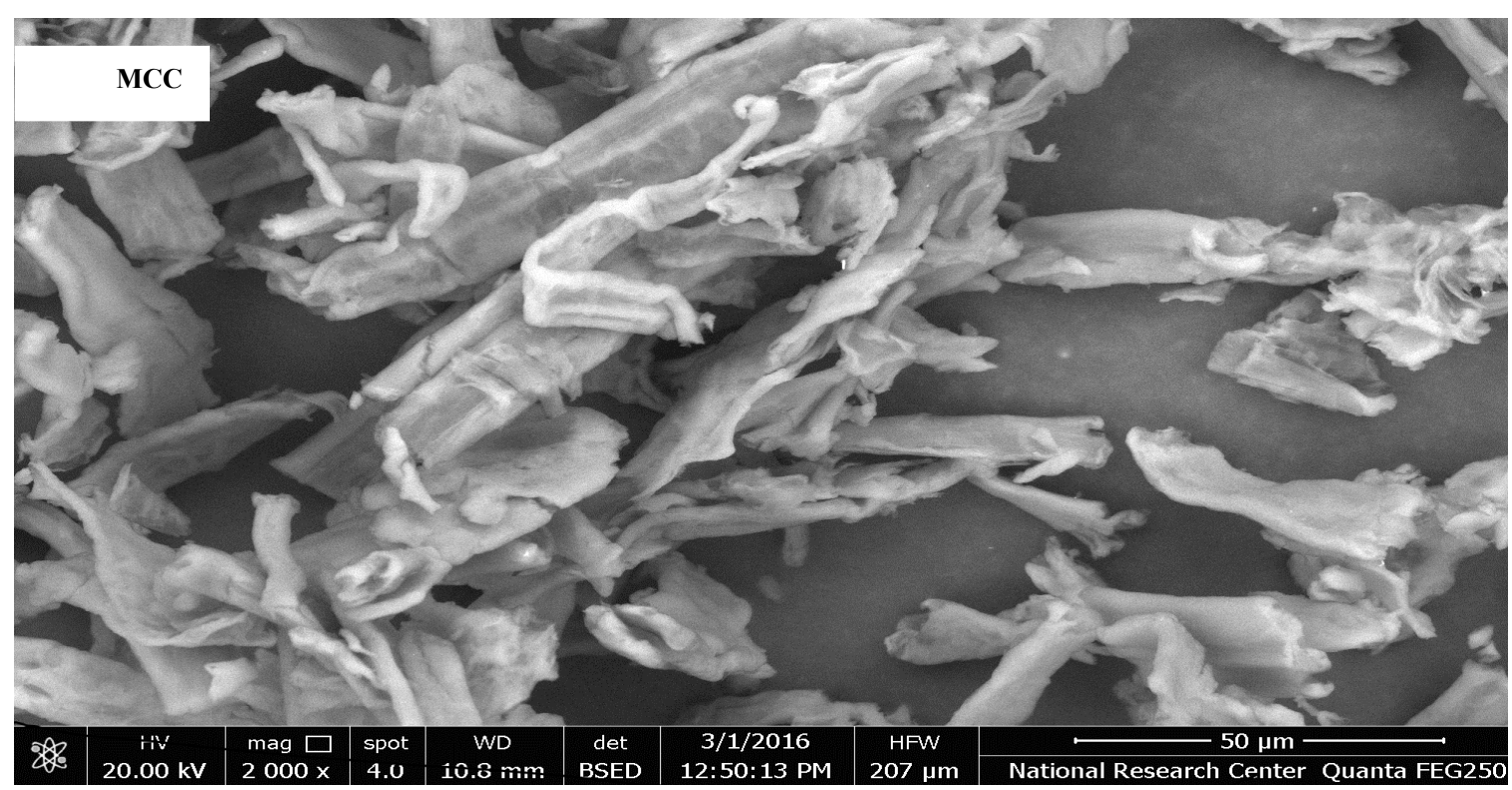

Egypt.J.Chem. 60 , No.3 (2017) 

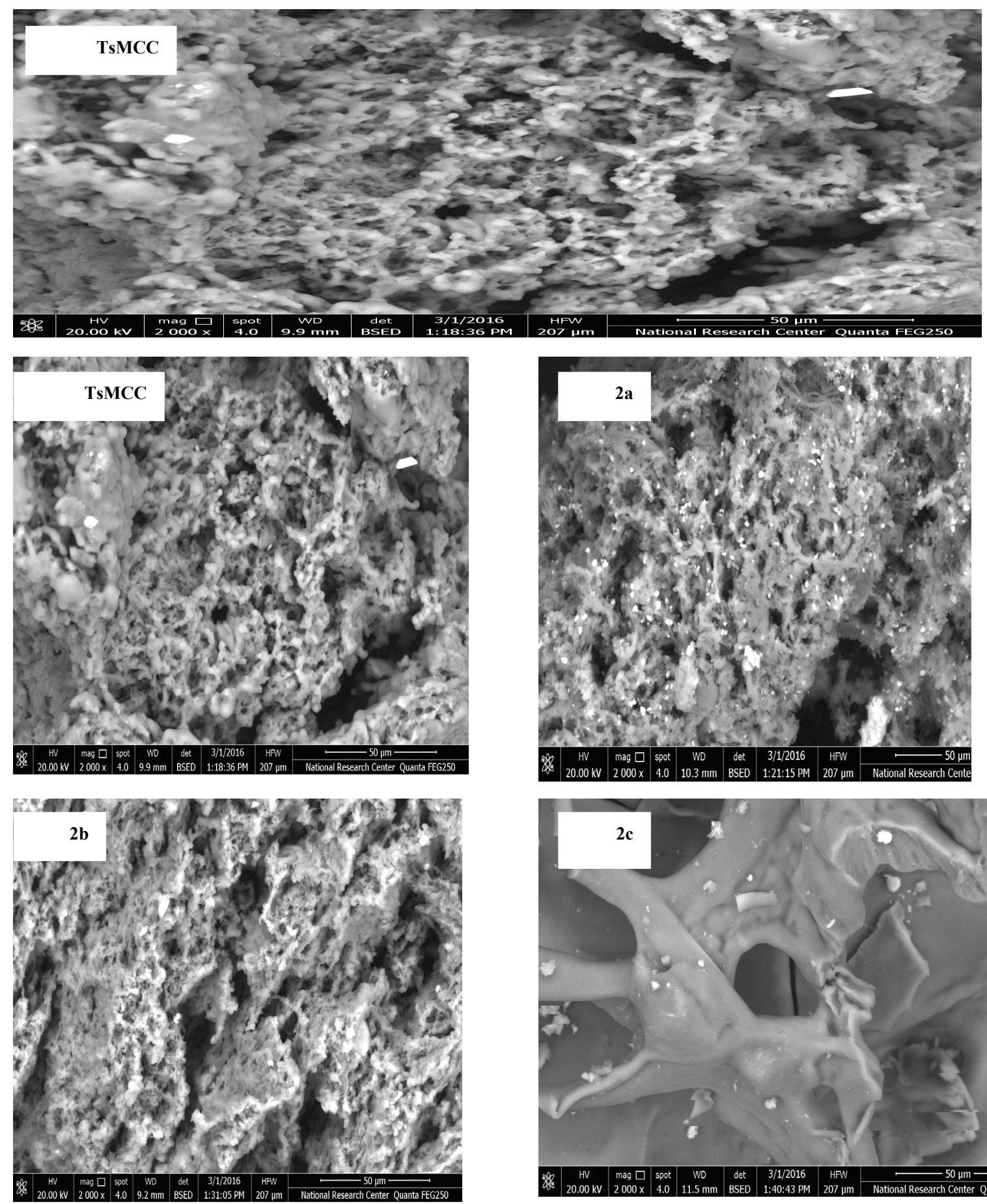

Fig.1. Characterization for MCC, TsMCC, and aminocellulose derivativesd (2a-c) .

opening, by breaking the bond between $\mathrm{C}-2$ and C-3 to obtain the corresponding 2,3-dialdehyde derivative 2,3- DACMC (Scheme 2). Following the method described by E. Bordallo et al.[22] The molar ratio of AGU: periodate was1:1.2 and the oxidation time was continued for $48 \mathrm{~h}$ at $35^{\circ} \mathrm{C}$, (Scheme 2).
The aldehyde content was determined by the oxime formation method described by U. J. Kim et a1.[30] and it was found to be $65 \%$. According to $\mathrm{H}$. Li et al.[31] the calculated value for $\mathrm{AC}$ is not equal to the whole aldehyde content on the chain due to the formation of hemiacetal bonds between the aldehyde groups, and the neighboring Egypt.J.Chem. 60 , No.3 (2017) 


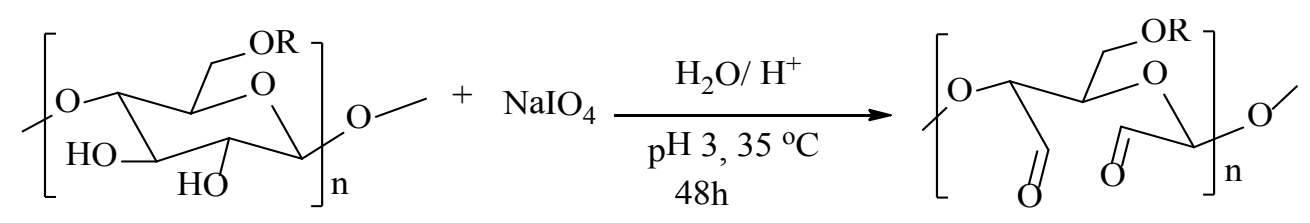

CMC

$\mathrm{R}=\mathrm{H}$ or $\mathrm{CH}_{2} \mathrm{COO} \stackrel{+}{\mathrm{Na}}$
2,3-DACMC

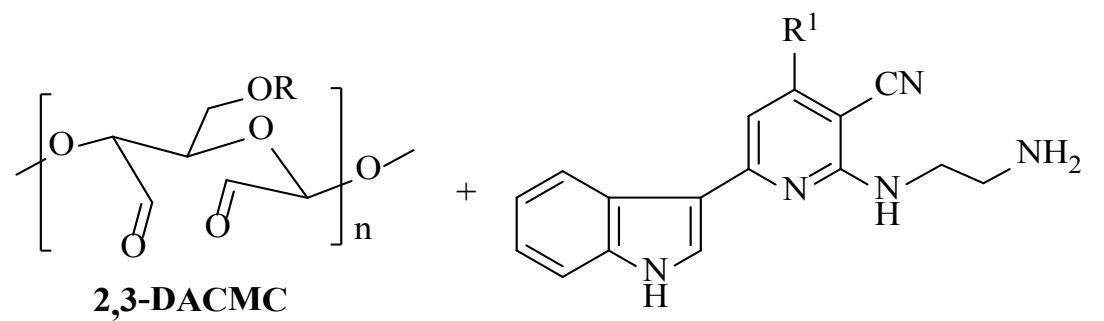

2,3-DACMC

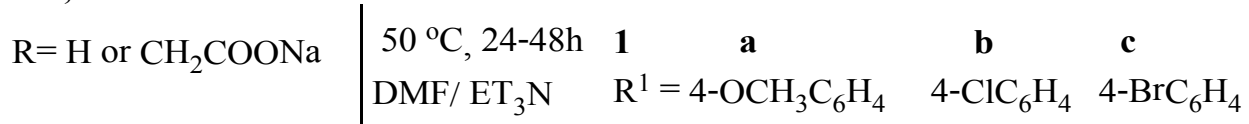

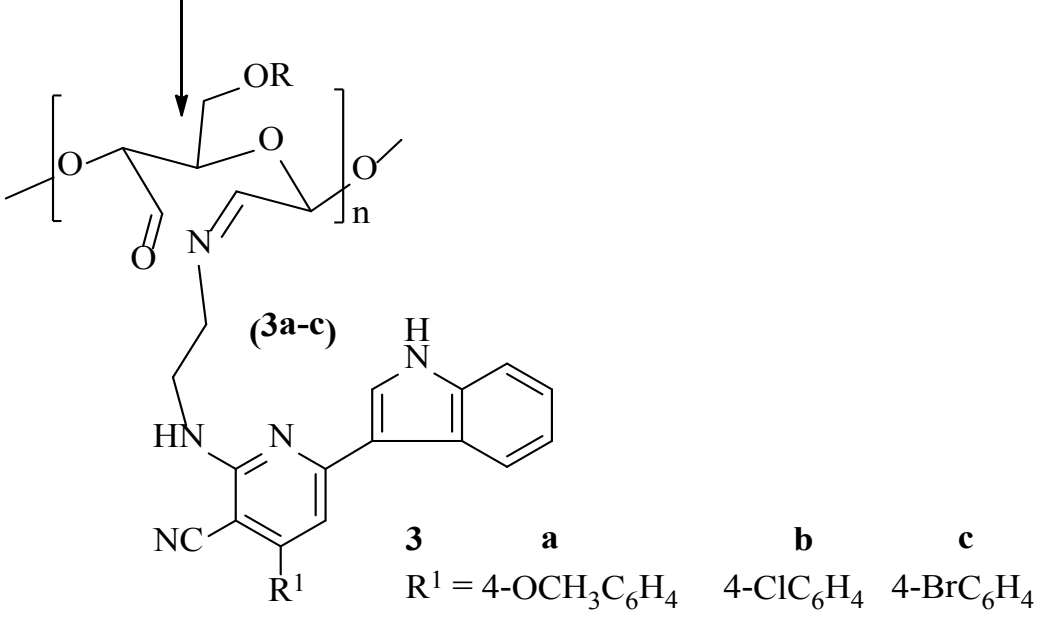

hydroxyl groups along the $\mathrm{CMC}$ backbone. The dialdehyde oxidation of CMC was confirmed by IR that displayed a stretching vibrational band at $1738 \mathrm{~cm}^{-1}$ corresponds to the aldehydic carbonyl groups while the band at $889 \mathrm{~cm}-1$ is assigned to the formation of the hemiacetal bond. This was consistent with the reported IR spectra for 2,3-DACMC[22, 29-31].

\section{Schiff's base formation}

2,3-DACMC was used as a precursor for the synthesis of some new antimicrobial hydrogels through the Schiff"s base reactions with the primary amino group of 2-aminoethylamino indolylnicotinonitrile derivatives (1a-c) TEA was used as a catalyst (Scheme 2). The structures of the products have been confirmed by FT-IR, elemental analysis, and XRD.
The IR for the Schiff"s base products (3ac) revealed the existence of the characteristic vibrational band which is assigned to the $(\mathrm{CN})$ group at $2202 \mathrm{~cm}^{-1}$ for (3a), $2204 \mathrm{~cm}^{-1}$ for (3b) and $2210 \mathrm{~cm}^{-1}$ for (3c). Additionally the appearance of new strong bending band for $(\mathrm{N}$ $\mathrm{H})$ at $1594 \mathrm{~cm}^{-1}$ for (3a), $1597 \mathrm{~cm}^{-1}$ for (3b) and $1578 \mathrm{~cm}^{-1}$ for $(3 \mathrm{c})$.

The X-Ray diffraction study for Schiff's bases.

The effect of periodate oxidation on CMC, and Schiff bases formation (3a-c) on the degree of crystallinity was studied. The sharp peaks in the XRD diffractogram patterns of 2,3-DACMC, and its Schiff's bases (3a-c) reveals their crystalline nature compared to CMC. Where the XRD pattern of CMC revealed the existence of three characteristic peaks at $2 \theta$ of 8.82 (73.79), 20.63o (100), 44.62 (33.20). The 
XRD pattern for (2,3-DACMC) showed peaks $2 \theta$ of 12.66 (100.00), 15.04 (95.52), 18.42 (63.62), 22.21 (75.46), 25.82 (66.30), 27.83 (50.52), 29.67 (83.75), 30.83 (24.95). for Schiff's base (3a), 20.71 (78.63), 21.78 (36.83), 27.83 (36.22), 30.27 (100). while Schiff's base (3b) the sharp peaks at $2 \theta$ of 12.73 (23.98), 22.89 (100), 25.79 (30.86), indicated the high crystalline arrangement of the polymer chains. For compound (3c), 20.76 (100), 21.83 (50.96), 27.92 (60.18), 30.32 (85.78), (Fig. 4). The crystalline nature of the Schiff" s bases may be due to the ability of hydrophobically modified 2,3-DACMC chains to be arranged in a well- packed structure. These results indicated that (1ac) condensed effectively with 2,3-DACMC. The projection of the Schiff bases along the $\mathrm{C}=\mathrm{N}$ axis resulted in an increase in the interchain distance, improving the organization of cellulose Schiff base [29-31].

Evaluation of the antimicrobial activity:

The antimicrobial activity of (1a-c, at $2 \mathrm{mg}$ / $\mathrm{mL}$ ), TsMCC, amino cellulose derivatives (2ac), 2,3-DACMC, and Schiff's bases (3a-c) were evaluated at concentrations $(200 \mathrm{mg} / \mathrm{mL})$ on four different potentially pathogenic microbial

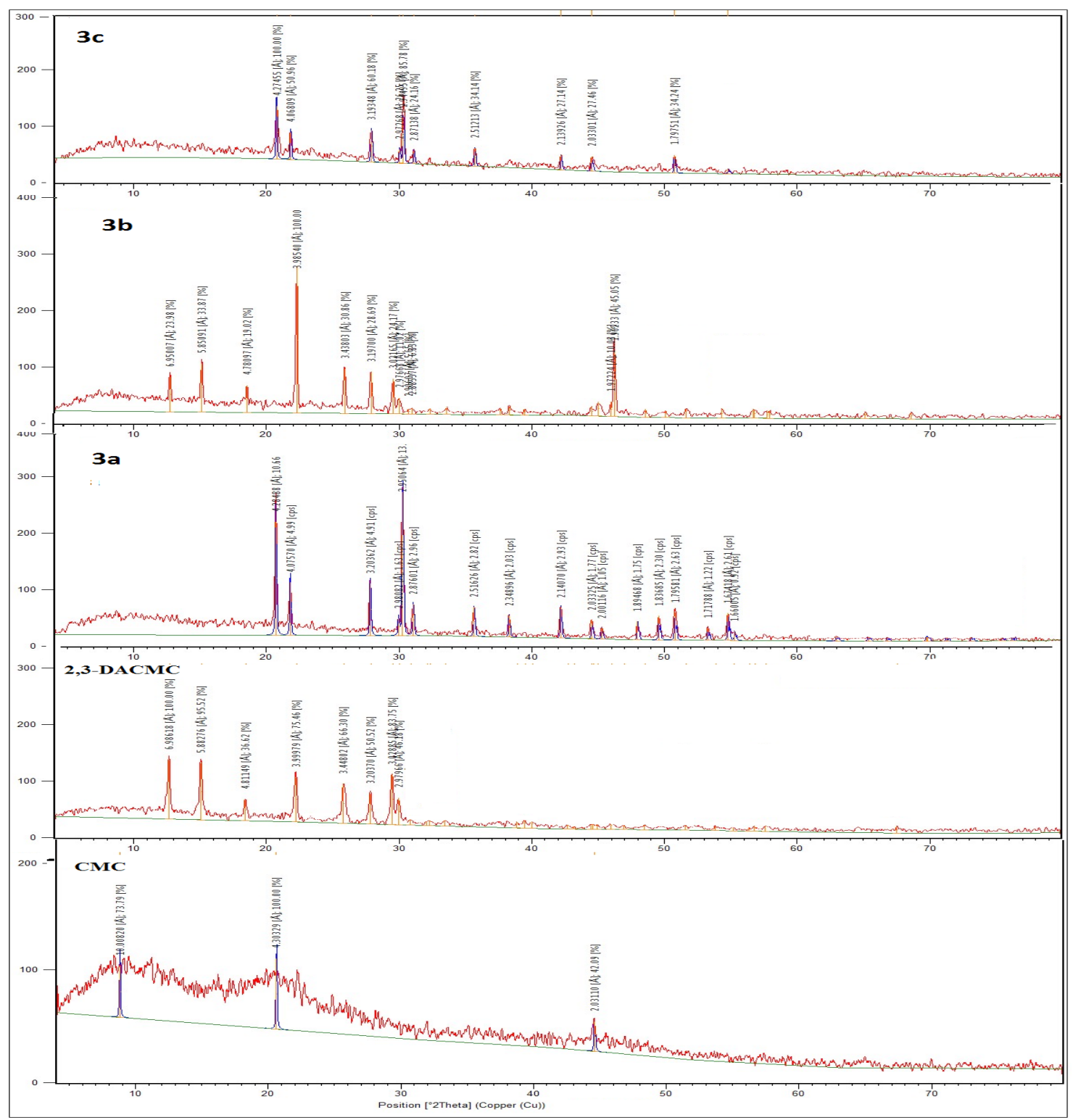

Fig.2. XRD for CMC, 2,3-DACMC, and Schiff 's bases (5-c). 
strains namely; Staphylococcus, and Bacillus subtilis (gram positive), Escherichia coli (gramnegative), and Candida (yeast) using well diffusion method the plates were incubated at $37^{\circ} \mathrm{C}$ for 24 hours and the inhibition zones around the wells were measured.

As we can see that 2-aminoethylamino indolylnicotinonitrile (1a) showed minor activity against Bacillus subtilis and Candida but they were not active against Staphylococcus aureus or E. coli. Meanwhile, compounds (1b) and (1c) had mild activity against gram-positive bacteria and candida, Meanwhile, they did not show any antibacterial activity against the gram-negative bacteria E.coli. Meaning that their activity is selective to the gram positive bacterial strains. The immobilization of the active heterocyclic amines on the surface of cellulose tosylate retarded the antimicrobial performance of the novel cellulose amine derivatives even at high concentrations (300 $\mathrm{mg} / \mathrm{ml})$. On the other hand, 2,3-DACMC and Schiff"s bases $3 \mathrm{a}$ and $3 \mathrm{~b}$ showed moderate, broad spectrum antimicrobial activity, while (3c) had low activity at $(200 \mathrm{mg} / \mathrm{mL})$, (Table 1$)$. The minimum inhibitory concentrations were determined for compounds 2,3-DACMC, (3a) and ( $3 b)$. Where, each microorganism was seeded by $100 \mu \mathrm{L}$ of each compound at three different concentrations $(50,100$, and $300 \mathrm{mg} / \mathrm{mL})$. By increasing the concentration to $300 \mathrm{mg} / \mathrm{mL}$ the diameter of inhibition zone increased, decreasing the concentration to $100 \mathrm{mg} / \mathrm{mL}$ the activity decreased. There was no activity for the tested compounds at $50 \mathrm{mg} / \mathrm{mL}$. In conclusion, Schiff"s bases (3a) and (3b) showed promising broad spectrum antimicrobial activity in particular at high polymer concentration therefore we can say that conjugating compounds (1a) and (1b) to 2,3-DACMC through Schiff's base formation increased the antimicrobial spectrum for the conjugates (3a) and (3b), and the potency for Schif sbases (3a) and (3b). On the other hand, conjugating (1c) to 2,3-DACMC diminished its activity.

\section{Conclusion}

In this study, we have introduced new heterocyclic grafted cellulose derivatives. Starting with microcrystalline cellulose, tosyl cellulose intermediates was prepared with DS 0.44 under homogeneous conditions in DMA $\backslash \mathrm{LiCl}$. The tosyl

TABLE 1. Inhibitory zone in (mm) at $2 \mathrm{mg} / 100 \mu \mathrm{L}$ of the polymer concentration and $200 \mu \mathrm{g} / 100 \mu \mathrm{L}$ of $(1 \mathrm{a}-\mathrm{c}))$.

\begin{tabular}{|c|c|c|c|c|}
\hline Compound & Bacillus subtilis & Staphylococcus aureus & Escherichia coli & Candida \\
\hline $50 \%$ DMSO & - & - & - & - \\
\hline $2,3-D A C M C$ & 5.66 & 3.3 & 2.5 & 5 \\
\hline 1a & 2 & - & - & 1.33 \\
\hline 1b & 4.3 & 3.67 & - & 3.67 \\
\hline Ic & 3.3 & 3.5 & 5.5 & 6 \\
\hline $3 \mathrm{a}$ & 5 & 3.67 & 6.5 & - \\
\hline $3 \mathrm{~b}$ & 4.3 & 1.67 & 1.33 & - \\
\hline $3 \mathrm{c}$ & - & - & & \\
\hline
\end{tabular}

TABLE 2. Inhibitory zone in ( $\mathrm{mm})$ at different polymer concentration.

\begin{tabular}{|c|c|c|c|c|}
\hline Microorganism & Conc. $\mathbf{m g} / \mathbf{m L}$ & $\mathbf{2 , 3 - D A C M C}$ & $\mathbf{3 a}$ & 3b \\
\hline Bacillus subtilis & 50 & - & - & - \\
\hline Bacillus subtilis & 100 & 4.5 & 5.5 & 4 \\
\hline Bacillus subtilis & 300 & 10 & 16 & 15 \\
\hline Staphylococcus aureus & 50 & - & - & - \\
\hline Staphylococcus aureus & 100 & 4.5 & 3.5 & 4 \\
\hline Staphylococcus aureus & 300 & 5.5 & 6.5 & 12 \\
\hline Escherichia coli & 50 & - & - & - \\
\hline Escherichia coli & 100 & 1.5 & 4 & 5 \\
\hline Escherichia coli & 300 & 6 & 6 & 10 \\
\hline Candida & 50 & - & - & - \\
\hline Candida & 100 & 4 & 4 & 3.5 \\
\hline Candida & 300 & 6 & 8 & 5.5 \\
\hline
\end{tabular}

Egypt.J.Chem. 60 , No.3 (2017) 
group underwent further nucleophilic replacement with 2-((2-Aminoethyl)amino)-6-(1H-indol3-yl)-4-aryl-nicotinonitriles derivatives (1a-c) which are reported to exhibit significant biological activity. Moreover, 2,3-DACMC was obtained by periodate oxidation of $\mathrm{CMC}$ and condensed with 2-((2-Aminoethyl)amino)-6-(1H-indol-3yl)-4-aryl-nicotinonitrile, affording Schiff's bases derivative. The antimicrobial results suggested that none of the prepared tosylated amino cellulose derivatives had antimicrobial activity, while out of the three Schiff's bases we prepared two of them have shown a good broad spectrum antimicrobial activity. Concluding that, incorporating compound 1a, or b into 2,3-DACMC via the Schiff's base reaction improved and increased the antimicrobial activity of CMC.

\section{$\underline{\text { References }}$}

1. Bao, B., Sun, Q., Yao, X., Hong, J., Lee, C.O., Sim, C.J., Im, K.S. and Jung, J.H., Cytotoxic bisindole alkaloids from a marine sponge Spongosorites sp. J. Nat. Prod., 68, 711-715 (2005).

2. Khidre, R.E., Abu-Hashem, A.A. and El-Shazly, M., Synthesis and antimicrobial activity of some 1-substituted amino-4, 6-dimethyl-2-oxo-pyridine-3carbonitrile derivatives. Eur. J. Med. Chem., 46, 50575064 (2011).

3. Gholap, A.R., Toti, K.S., Shirazi, F., Kumari, R., Bhat, M.K., Deshpande, M.V. and Srinivasan, K.V., Synthesis and evaluation of antifungal properties of a series of the novel 2-amino-5-oxo-4-phenyl-5, 6, 7, 8-tetrahydroquinoline-3-carbonitrile and its analogues. Bioorg. Med. Chem., 15, 6705-6715 (2007).

4. Manikannan, R., Muthusubramanian, S., Yogeeswari, P. and Sriram, D., Selective one-pot multicomponent synthesis and anti-tubercular evaluation of 5-(aryl/ cyclohexylsulfanyl)-2-alkoxy - 4,6-diarylnicotinonitriles. Bioorg. Med. Chem. Lett., 20, 3352-3355 (2010).

5. Attaby, F. A., Ramla, M.M. and Gouda, E.M., Synthesis, reactions, and biological activity of 4 (1 h-indol-3-yl)-2-thioxopyridine derivatives. Phosphorus, Sulfur, and Silicon, 182, 517-528 (2007).

6. Hamdy, N.A. and Gamal-Eldeen, A.M., New pyridone, thioxopyridine, pyrazolo-pyridine and pyridine derivatives that modulate inflammatory mediators in stimulated RAW 264.7 murine macrophage. Eur. J. Med. Chem, 44, 4547-4556 (2009).

7. Zhao, L.X., Moon, Y.S., Basnet, A., Kim, E.K., Jahng, Y., Park, J.G., Jeong, T.C., Cho, W.J.,
Choi, S.U., Lee, C.O. and Lee, S.Y., Synthesis, topoisomerase I inhibition and structure-activity relationship study of 2, 4, 6-trisubstituted pyridine derivatives. Bioorg. Med. Chem. Let., 14, 1333 1337 (2004).

8. Thapa, P., Karki, R., Choi, H., Choi, J.H., Yun, M., Jeong, B.S., Jung, M.J., Nam, J.M., Na, Y., Cho, W.J. and Kwon, Y., Synthesis of 2-(thienyl-2-yl or-3-yl)4-furyl-6-aryl pyridine derivatives and evaluation of their topoisomerase I and II inhibitory activity, cytotoxicity, and structure-activity relationship. Bioorg. Med. Chem., 18, 2245-2254 (2010).

9. Serry, A.M., Luik, S., Laufer, S. and Abadi A.H., One-Pot Synthesis of 4, 6-Diaryl-2-oxo (imino)-1, 2-dihydropyridine-3-carbonitrile; a New Scaffold for p38 a MAP Kinase Inhibition. J. Comb. Chem., 12, 559-565 (2010).

10. El-Sayed, N.S., Shirazi, A.N., El-Meligy, M.G., El-Ziaty, A.K., Rowley, D., Sun, J., Nagib, Z.A. and Parang, K., Synthesis of 4-aryl-6indolylpyridine-3-carbonitriles and evaluation of their antiproliferative activity. Tetrahedron lett., 55, 1154-1158 (2014).

11. Zarth, C.S.P., Koschella, A., Pfeifer, A., Dorn, S., and Heinze, T., Synthesis and characterization of novel amino cellulose esters. Cellulose, 18, 13151325 (2011).

12. Jung, A., and Berlin, P., New water-soluble and film-forming aminocellulose tosylates as enzyme support matrices with $\mathrm{Cu} 2+$-chelating properties. Cellulose, 12, 67-84 (2005).

13. Saikrishnan, D., Goyal, M., Rossiter, S. and Kukol, A.A., Cellulose-based bioassay for the colorimetric detection of pathogen DNA. Anal Bioanal. Chem., 406, 7887-7898 (2014).

14. Zieger, M., Wurlitzer, M., Wiegand, C., Reddersen, K., Finger, S., Elsner, P. and Hipler, U.C. 6-Deoxy6-aminoethyleneamino cellulose: synthesis and study of hemocompatibility. J. Biom. Sci., Poly. Ed., 26, 931-946 (2015).

15. Heinze, T., Genco, T., Petzold-Welcke, K. and Wondraczek, H., Synthesis and characterization of aminocellulose sulfates as novel ampholytic polymers. Cellulose, 19, 1305-1313 (2012) .

16. Nikolajski, M., Wotschadlo, J., Clement, J.H. and Heinze, T., Amino-functionalized cellulose nanoparticles: preparation, characterization, and interactions with living cells. Macromol. Biosci., 12, 920-925 (2012).

17. Agag, T., Vietmeier, K., Chernykh, A. and Ishida, H., Side-chain type benzoxazine-functional cellulose via click chemistry. J. Appl. Poly. Sci., 125, 1346-1351 (2012). 
18. Littunen, K., de Castro, J.S., Samoylenko, A., $\mathrm{Xu}$, Q., Quaggin, S., Vainio, S., and Seppälä, J., Synthesis of cationized nanofibrillated cellulose and its antimicrobial properties. Eur. Poly. J., 75, 116-124 (2016).

19. Rabea, E. I., Badawy, M. E. T., Stevens, C. V., Smagghe, G., and Steurbaut, W., Chitosan as antimicrobial agent: applications and mode of action. Biomacromol., 4, 1457-1465 (2003).

20. Ernsting, M. J., Tang, W. L., MacCallum, N. and Li, S. D., Synthetic modification of carboxymethylcellulose and use thereof to prepare a nanoparticle forming conjugate of docetaxel for enhanced cytotoxicity against cancer cells. Bioconj. Chem., 22, 2474-2486 (2011).

21. Fan, L., Peng, M., Zhou, X., Wu, H., Hu, J., Xie, W. and Liu, S., Modification of carboxymethyl cellulose grafted with collagen peptide and its antioxidant activity. Carbohyd. Poly, 112, 32-38 (2014).

22. Bordallo, E., Rieumont, J., Tiera, M.J., Gómez, M. and Lazzari, M., Self-assembly in aqueous solution of amphiphilic graft copolymers from oxidized carboxymethylcellulose. Carbohyd. Poly, 124, 4349 (2015).

23. Sinha, D., Tiwari, A.K., Singh, S., Shukla, G., Mishra, P., Chandra, H. and Mishra, A. K., Synthesis, characterization and biological activity of Schiff base analogues of indole-3-carboxaldehyde. Europ. J. Med. Chem., 43, 160-165 (2008).

24. Gurkok, G., Altanlar, N. and Suzen, S., Investigation of antimicrobial activities of indole- 3 -aldehyde hydrazide/hydrazone derivatives. Chemotherapy, 55(1), 15-19 (2008).

25. Thygesen, A., Oddershede, J., Lilholt, H., Thomsen, A. B. and Ståhl, K., On the determination of crystallinity and cellulose content in plant fibres. Cellulose, 12, 563-576 (2005).

26. Rahn, K., Diamantoglou, M., Klemm, D., Berghmans, $H$. and Heinze, T. Homogeneous synthesis of cellulose p-toluenesulfonates in N,Ndimethyl acetamide/LiCl solvent system. Die Ange. Makromol. Chem., 238, 143-163 (1996).

27. McCormick, C.L., Dawsey, T. R. and Newman, J. K., Competitive formation of cellulose p-toluenesulfonate and chlorodeoxycellulose during homogeneous reaction of p-toluenesulfonyl chloride with cellulose in N, N-dimethylacetamidelithium chloride. Carbohyd. Res, 208, 183-191 (1990).

28. Nikolajski, M., Wotschadlo, J., Clement, J.H. and Heinze, T., Amino-functionalized cellulose nanoparticles: preparation, characterization, and

Egypt.J.Chem. 60 , No.3 (2017) interactions with living cells. Macromol. Biosci., 12, 920-925 (2012).

29. Li, H., Wu, B., Mu, C. and Lin, W., Concomitant degradation in periodate oxidation of carboxymethyl cellulose. Carbohyd. Poly, 84, 881-886 (2011).

30. Kim, U.J., Kuga, S., Wada, M., Okano, T. and Kondo, T., Periodate oxidation of crystalline cellulose. Biomacromol., 1, 488-492 (2000).

31. Li, J., Wan, Y., Li, L., Liang, H. and Wang, J., Preparation and characterization of 2, 3-dialdehyde bacterial cellulose for potential biodegradable tissue engineering scaffolds. Mat. Sci. Eng. C, 29, 1635-1642 (2009).

32. Bauer, A.W., Kirby, W.M.M., Sherris, J.C. and Turck, M., Antibiotic susceptibility testing by a standardized single disk method. Am. J .Clin. Path., 45, 493 (1966).

(Receieved 23/11/2016 Accepted 21/1/2017) 


\section{تحضير مواد سليلوزيه جليده كمضادات ميكروبيه،باستخدام مشتقات الأمينـو إندوليل نيكوتينـونـيتريل}

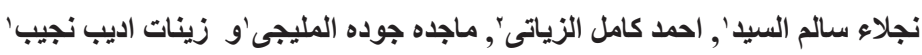

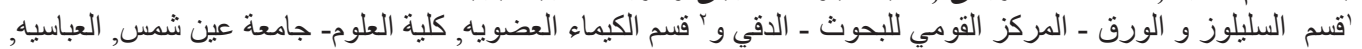

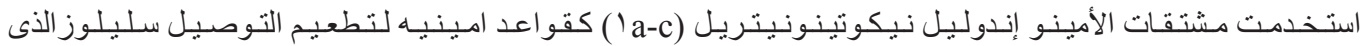

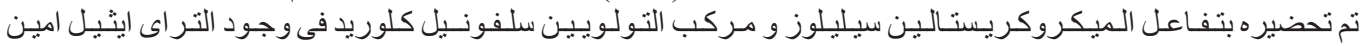

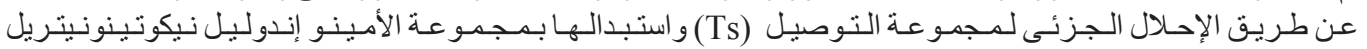

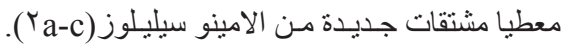

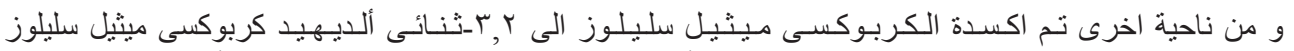

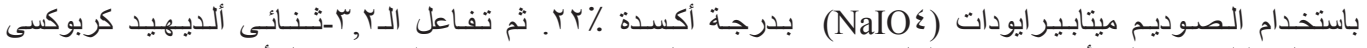

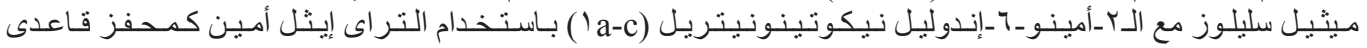

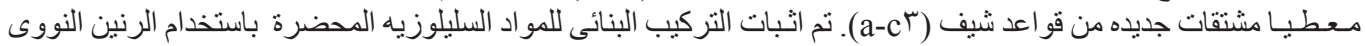
المغناطيسى , الاشعه تحت الحمر اء, المسح الاكترونى الميكروسكوبى, و الآشعة السينيه.

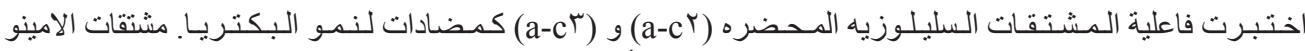

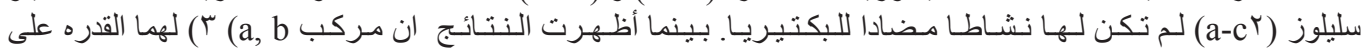

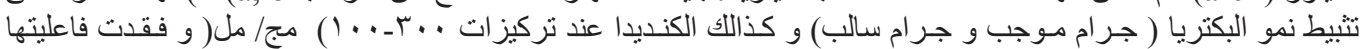

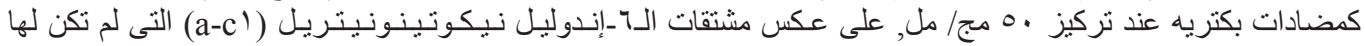
فاعليه ضد بكتريا جر ام سالب. تُكن. 